\title{
Evaluation of Dry Peas (Pisum sativum L.) Varieties for Seedling Vigor Indices in Eastern Montana
}

\section{Authors: Maninder Walia, Yesuf Assen Mohammed, \& Chengci Chen}

This is an Accepted Manuscript of an article published in Communications in Soil Science and Plant Analysis on [date of publication], available online:

http://www.tandfonline.com/10.1080/00103624.2017.1416138.

Walia, Maninder, Yesuf Assen Mohammed, and Chengci Chen. "Evaluation of Dry Peas (Pisum sativum L.) Varieties for Seedling Vigor Indices in Eastern Montana." Communications in Soil Science and Plant Analysis 48, no. 22 (December 2017): 2652-2662. DOI: 10.1080/00103624.2017.1416138.

Made available through Montana State University's $\underline{\text { ScholarWorks }}$ scholarworks.montana.edu 


\title{
Evaluation of Dry Peas (Pisum sativum L.) Varieties for Seedling Vigor Indices in Eastern Montana
}

\author{
Maninder Kaur Walia ${ }^{a}$, Yesuf Assen Mohammed ${ }^{b}$, and Chengci Chen ${ }^{b}$ \\ aDepartment of Agronomy and Plant Genetics, University of Minnesota, Morris, MN, USA; bEastern Agricultural \\ Research Center, Montana State University, Sidney, Montana, USA
}

\begin{abstract}
Genetic and environmental factors lead to a variation in yield and protein content of dry pea (Pisum sativum L.) seeds. The quality of seed, particularly seed vigor, also influences the establishment of crop and thus final grain yield. The area and production for dry peas are increasing in the Northern Great Plains but knowledge is lacking on how the pea lines/varieties differ in the seed vigor at seven leaf stage. This field and greenhouse study evaluated the eight dry pea lines/varieties for seedling vigor indices and correlated them with grain yield and protein concentrations. Significant differences were observed among the lines/varieties for nodule number plant ${ }^{-1}$ in greenhouse, and grain yield in field conditions. The highest number of nodules plant ${ }^{-1}$ was obtained with the line MT632, which were at par with lines MT457, and MT190. The highest Vigor Index I was achieved with line MT632 associated with their more shoot lengths as compared to other lines/varieties. The highest Vigor Index II was obtained by variety Majoret and line MT632. The variety DS Admiral yielded $5205 \mathrm{~kg}$ $\mathrm{ha}^{-1}$, which was 17.4 and $33.3 \%$ higher than lines MT460 and MT190, respectively. The highest seed protein content was obtained with variety Majoret (23.4\%) having highest Vigor Index II and seed yield (4940 kg ha $\left.{ }^{-1}\right)$ at par with variety DS Admiral. The lowest seed protein was found with variety DS Admiral (20.3\%). The line named MT190 showed lowest yield potential along with the lower protein contents also. Studies show a positive and significant correlation between biomass and Vigor Index I only. Plant nitrogen uptake was positively and significantly correlated with biomass and Vigor Index I in greenhouse only. The results also indicated that seed vigor indices did not reveal any significant correlations with dry peas yield and protein content, so more efforts are needed to evaluate varieties for higher yield and protein content during initial stages of growth in order to maximize their acreage and productivity.
\end{abstract}

\section{Introduction}

To increase profitability and sustainability of agriculture, the crop diversification plays an important role (Hatfield and Karlen 1994). Earlier studies (Chen et al. 2012; Miller et al. 2002) have shown that pulse crops can play a much greater role for diversifying wheat-based cropping systems in the Northern Great Plains (NGP) and at present, pea is increasingly being rotated with wheat crop in Montana (Miller et al. 2015). Moreover, new market opportunities and processing facilities have encouraged farmers to increase the area sown to adapted legumes. For instance, in Montana, the dry pea production area is increasing and has reached to 240,000 ha in 2015 , placing the state the top dry pea producer in the USA (USDA-NASS 2016). Legumes play an important role in improving the soil fertility in the rotation systems with cereal crops, by fixing the atmospheric nitrogen and thus adding to the pool of soil nitrogen and improve the yields of cereal crops (Chalk et al. 1993; Herridge et al. 1995). 
Pulses also play an important role in the diet of most of the people in the world. Dry peas are the second most important food legume grown worldwide after common beans (Phaseolus vulgaris L.) (Tar'an et al. 2004; Wang and Daun 2004). Among legume crops, dry peas apart from soybeans and lentils provide high nutritional value resulted from a well-balanced amino acid composition of the protein and relatively low content of antinutrients (Borowska, Zadernowski, and Konopka 1996). Due to the rich source of protein, peas are also grown for hay, pasture, or silage production, either alone or mixed with cereals, in different parts of the world (Chen et al. 2004; Mckenzie and Spooner 1999).

Earlier studies (Robertson et al. 1962; Eppendorfer and Bille 1974; McLean et al. 1974; Wang and Daun 2004; Nikolopoulou et al. 2007; Wang et al. 2010) have shown that the yield and protein content of dry peas vary with environmental and genetic factors. Genotypes respond to changes in environmental conditions such as temperature, rainfall, soil type, and moisture (Falconer and Mackay 1995; Acikgoz et al. 2009).

An interaction between seedbed environment and quality of seed also influences the establishment of crop and final yield (Khajeh-Hosseini, Powell, and Bingham 2003). Powell et al. (1984) also found that differences in vigor levels of seed lots lead to differences in crop establishment and yield, especially in grain legumes. Atak et al. (2008) found a significant difference in seed vigor of three dry pea genotypes cvs. "Rondo," "Carina," and "Jof" with each genotype producing a mixture of light (L), medium (M), and dark (D) green seed at maturity.

The major determinant of seed quality, particularly seed vigor is an environment experienced by plants during seed development (Delouche 1980). Seed vigor is an important seed quality factor, which describes the potential of seed for rapid and uniform emergence and the development of normal seedlings under a wide range of field conditions (Perry 1987). Seed vigor is an interaction of characteristics, which can be considered as an independent attributes of physiological potential such as speed of germination, seedling growth, ability to germinate above or below optimal temperatures, and other aspects of tolerance to stresses (Marcos-Filho 2015). A vigorous seed lot is one that is potentially able to perform well under not optimal environmental conditions for the species (ISTA 2014). Vigorous seeds are usually expected to recover from the stress conditions often found in the fields and can result in high crop productivity. Many factors such as seed size, seed maturity, genetic constraints, and growth conditions of the mother plant can cause the differences in seed vigor (ISTA 1995). The rapid and uniform emergence of vigorous seedlings of the desired variety is important to ensure high plant performance that finally affects uniformity of development, competition against weeds, yield, and quality of the harvested product. Dias et al. (2010) found that vigor of seed is directly related to initial crop growth and affects plant competitive ability against weeds with their inferior growth rates.

Seed vigor is the combination of characteristics that determine the potential of seed for high performance after seeding (Marcos-Filho 2015). The various techniques that are used for assessment of seed vigor in different crops are accelerated aging (Helmer, Delouche, and Lienhard 1962), cold test (Caseiro and Marcos-Filho 2000), electrical conductivity (Matthews and Bradnock 1967), tetrazolium (Bhéring et al. 1999; Bittencourt and Vieira 1999), automated computer imaging (Chiquito, Gomes-Junior, and Marcos-Filho 2012), and tests that evaluate seedling growth (Matthews and Khajeh-Hosseini 2007). The tests that are based on seedling performance includes first count of the germination, speed of germination or seedling emergence, growth of the seedling (length or dry weight), seedling vigor classification, and more recently the emergence rate of the primary root (Marcos-Filho 2015).

Seed yield and protein content vary among different legume crop varieties. Mohammed et al. (2016) found that an average grain yield among dry pea genotypes varied from 2243 to $2680 \mathrm{~kg} \mathrm{ha}{ }^{-1}$ in Montana. Ali-Khan and Youngs (1973) found significant differences in pea protein content, which varied among cultivars, locations, and years and reported that an average protein content among cultivars varied from 23.1 to $28.3 \%$, among locations from 24.0 to $26.3 \%$, and among years from 25.8 to $27.4 \%$. So, the need exists for a test which would give a better indication of the growth, yield, and harvest quality of different dry pea lines/varieties that is not detected by viability tests and rank the lines/varieties according to their seed protein content and also yield potential. The basic objective of seed vigor testing is to provide a precise identification among different dry pea lines/varieties, mostly 
with those of similar germination percentage, with higher protein concentration and yields. The effects of garden pea seed vigor on field establishment are well studied (Bedford 1974; Perry 1967, 1969, 1970; Scott and Close 1976a). However, evaluation of different field pea varieties for early growth and seedling vigor indices and how they correlate to agronomic parameters have not been assessed. We hypothesize that variation in field pea lines/varieties would result in significant differences in early growth, seedling vigor indices, thus causing a significant differences in the seed protein content and yield. Therefore, the objectives of this study were (1) to determine the differences of field pea lines/ cultivars with regard to early growth, seedling vigor indices at seven-leaf stage in greenhouse, (2) to find the relationship of these results with the field seed protein content, and yield, and (3) to find the correlation of seedling vigor indices observed in greenhouse and incubation studies with field studies.

\section{Materials and methods}

A field experiment was conducted at the Eastern Agricultural Research Center (EARC), Montana State University in Sidney, Montana $\left(47^{\circ} 40^{\prime} \mathrm{N}, 104^{\circ} 08^{\prime} \mathrm{W} ; 670 \mathrm{~m}\right.$ elevation). The soil at the experiment site is a deep, well drained, nearly level Savage clay loam (fine, smectitic, frigid Vertic Argiustolls) formed in alluvium parent material (www.ftw.nrcs.usda.gov) with the following characteristics: $3.8 \%$ organic matter; $\mathrm{pH}$ of $8.0 ; 125.9 \mathrm{~kg} \mathrm{ha}^{-1}$ nitrate-nitrogen; $24.3 \mathrm{mg} \mathrm{kg}^{-1}$ Olsen phosphorus; $43.7 \mathrm{mg} \mathrm{kg}^{-1}$ sulfate sulfur; and $440 \mathrm{mg} \mathrm{kg}^{-1}$ potassium. Weather parameters, including cumulative precipitation and average temperature during growing season, are shown in Table 1. Crops were irrigated with sprinkler irrigation and total amount of $381 \mathrm{~mm}$ of water was applied throughout the crop season with irrigation system. No fertilizers were applied prior to crop seeding. Treatments included were eight lines/varieties of field peas, named as Delta, DS Admiral, Majoret, Cruiser, MT632, MT460, MT457, and MT190 and conducted on a randomized complete block design with four replications. The plot size was $5.6 \mathrm{~m}^{2}$ and the spacing between the rows was kept at $0.30 \mathrm{~m}$. Seeds were sown on April 21, 2016 at a rate of 86 seeds $\mathrm{m}^{-2}$ and drilled at a depth of $0.05 \mathrm{~m}$. Commercial peat powder rhizobia inoculant named BioSinc (Timac Agro, PA, USA) was applied to seed prior to planting. Seeds were pretreated with fludioxinyl and mefenoxam fungicide (Apron Maxx RTA, Syngenta, Greensboro, NC) at a rate of $3.25 \mathrm{~mL}^{\text {a.i. }} \mathrm{kg} \mathrm{seed}^{-1}$ and thiamethoxam insecticide (Cruiser MAXX ${ }^{\oplus}$, Syngenta, Basel, Switzerland) at a rate of $1.0 \mathrm{~mL}$ a.i. $\mathrm{kg} \mathrm{seed}^{-1}$ to control soil-borne diseases and pea leaf weevil infestation, respectively, before seed treatment with rhizobium inoculant. After physiological maturity, the plots were harvested on July 29, 2016 using a small plot combine. Seeds were weighed for each plot after harvest for yield determination. The grain yield was adjusted to $13 \%$ moisture content prior to statistical analysis. The grain protein concentration was also estimated simultaneously using Infratec ${ }^{\mathrm{TM}}$ 1241 grain analyzer (FOSS Analytical AB, Sweden).

A small sample of seed that was used for the field study was collected from each variety/genotype for a greenhouse study. The greenhouse study was conducted at EARC Research and Education Greenhouse of Montana State University. The experimental pots $(21.5 \mathrm{~cm}$ diameter and $22 \mathrm{~cm}$ high) were filled with about $6 \mathrm{~kg}$ of sieved soil ( $2 \mathrm{~mm}$ sieve) collected from top $15 \mathrm{~cm}$ soil depth of the same field for the above-mentioned field study and experiment was conducted on a randomized complete block design with six replications, making total of 48 experimental units. Seeds were sown in August 2016 as 10 seeds/pot planted to a depth of about $3 \mathrm{~cm}$. Commercial peat powder rhizobia inoculant and

Table 1. Cumulative monthly air temperature and average monthly rainfall along with their long-term average during the dry peas growing season.

\begin{tabular}{lcccc}
\hline & \multicolumn{2}{c}{ Temperature $\left({ }^{\circ} \mathrm{F}\right)$} & \multicolumn{2}{c}{ Rainfall $(\mathrm{cm})$} \\
\cline { 2 - 5 } Month & Monthly average & Long-term average & Monthly average & Long-term average \\
\hline May & 55.9 & 56.1 & 5.23 & 5.51 \\
June & 63.5 & 64.5 & 3.56 & 7.01 \\
July & 67.6 & 70.0 & 6.91 & 5.33 \\
August & 67.5 & 68.7 & 1.96 & 3.73 \\
September & 66.6 & 57.8 & 6.78 & 3.23 \\
\hline
\end{tabular}


seed treatment are the same as field study. The pots were watered uniformly to ensure good germination and establishment. All experimental pots received equal amount of water throughout the experimental time period to ensure only variety to be the variable factor. The greenhouse conditions were set at $16 \mathrm{~h} \mathrm{light} / 8 \mathrm{~h}$ dark period, temperature $21^{\circ} \mathrm{C} / 18^{\circ} \mathrm{C}$ (day/night), and relative humidity $50 \pm 5 \%$ throughout the experimental period.

Ten days after seeding, plants in each pot were counted to determine the seedling emergence and then at seven leaf stage, the plants were harvested to do early growth measurement and seedling vigor indices. Each plant in a single pot was uprooted carefully and washed to measure the number of nodules plant ${ }^{-1}$, shoot height, root height, and biomass of root and shoot after drying them at $65^{\circ} \mathrm{C}$ for 4 days. The total fresh weight of nodules was also measured for all established plants/pot. The dried above and below-ground biomass samples were ground to pass through a 1-mm mesh screen and then analyzed for total $\mathrm{N}$ (Dumas method using LECO TruSpec CN, Henderson, NV) (Sweeney 1989). The N uptake (g/pot) was calculated by (multiplying the $\mathrm{N}$ concentration with the dry matter)/100.

In addition to the greenhouse study, the same set of seeds was also tested in an incubator for vigor. In the incubator, 15 seeds/variety or line in replication of four were kept moist on germination trays for 8 days at $30^{\circ} \mathrm{C}$ to measure the seedling vigor characteristics, i.e., length $(\mathrm{cm})$ of the seedling (radicle and plumule), and dry weights (g) of seedling (radicle and plumule) after drying at $65^{\circ} \mathrm{C}$. Ten seedlings were randomly taken to measure these characteristics.

Seedling vigor indices for greenhouse and incubation studies were calculated using following formula $(1,2)$ (Abdul-Baki and Anderson 1973) as

$$
\begin{gathered}
\text { Vigor Index I = Germination } \% \times \text { seedling length } \\
\text { Vigor Index II }=\text { Germination } \% \times \text { seedling dry weight }
\end{gathered}
$$

\section{Statistical analysis}

Data were subjected to analysis of variance (ANOVA) using Proc Mixed of SAS (SAS 2001). Means were separated using Fisher's LSD test at $p<0.05$ after ANOVA gave significant F-values. Pearson correlation coefficients between pairs were determined using same data values.

\section{Results and discussion}

\section{Field study}

Yield of different lines/varieties varies from $3905-5205 \mathrm{~kg} \mathrm{ha}^{-1}$ with a mean value of $4745 \mathrm{~kg} \mathrm{ha}^{-1}$. A significant difference was observed among different lines/varieties based upon grain yield (Table 2). The variety DS Admiral yielded significantly higher $\left(5205 \mathrm{~kg} \mathrm{ha}^{-1}\right)$ as compared to lines MT460 and MT190 $(p=0.0286)$. The yield of DS Admiral was 17.4 and $33.3 \%$ higher as compared to these two lines, i.e., MT460 and MT190, respectively. Similarly, Mohammed et al. (2016) reported that dry pea varieties Montech 4152 followed by SW Midas and DS Admiral showed combination of better yield performance and stability in a diverse range of environments in temperate semi-arid climates. They found that the highest mean yield $\left(5627 \mathrm{~kg} \mathrm{ha}^{-1}\right.$ ) was recorded for variety DS Admiral at Creston, Montana and the lowest mean yield $\left(978 \mathrm{~kg} \mathrm{ha}^{-1}\right.$ ) was recorded for Cruiser at Bozeman, Montana.

In contrast to yield, seed protein content (grain nitrogen content multiplied by a factor of 6.25) for various pea lines/varieties varies from 20.3 to $23.4 \%$, but they were not significantly different $(p=0.3450$, Table 2), with a mean value of $21.9 \%$. The highest seed protein content was obtained with variety Majoret, while lowest was achieved with highest yielding variety DS Admiral. The results also showed that variety Majoret has higher yield potential $\left(4940 \mathrm{~kg} \mathrm{ha}^{-1}\right)$ similar to DS Admiral, along with highest protein content $(23.4 \%)$. Atta et al. (2004a) reported that protein content varies significantly between nodes of different genotypes, indicating genetic variability for this variation in protein content, which could be attributed to the difference between genotypes in the ability to maintain nitrogen fixation 


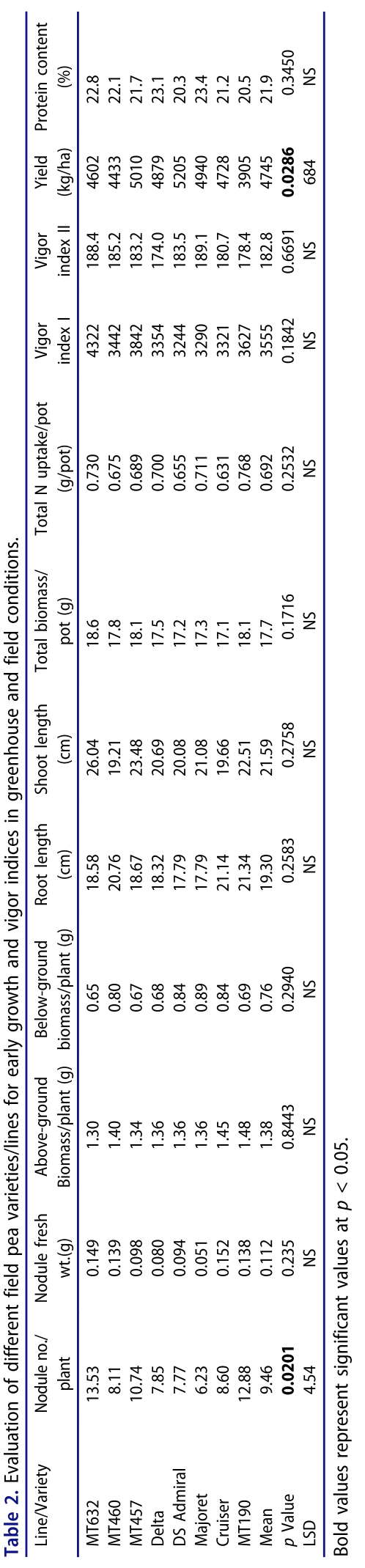


during the onset of seed filling. In addition, changes in seed nitrogen concentrations were mainly caused by variations in the seed nitrogen accumulation rates and also dependent on availability of nitrogen within the plant, transfer of nitrogen from the vegetative components of the plant (Pate et al. 1977; Cox, Qualset, and Rains 1985a; Lhuillier-Sondélé et al. 1999b; Salon et al. 2001; Atta et al. 2004b). Yoneyama and Ishizuka (1982) found that during seed filling period, symbiotically fixed nitrogen is preferentially transferred to growing seeds while mineral $\mathrm{N}$ (nitrogen) is equally distributed between seeds and mature vegetative organs. It has also been shown that total $\mathrm{N}$ varies within plants and with location and year (Ali-Khan and Youngs 1973), with maturity (Pandey and Gritton 1975). Grain nitrogen or grain protein concentrations are dependent not only on grain nitrogen content but also on grain carbohydrate content (Cataldo et al. 1975b). High protein concentrations in seeds were found not to be related to higher protein accumulations, but rather to low carbohydrate levels in seeds (Singhal, Srivastava, and Mehta 1989); water deficit and high temperature are also associated with low seed yield and elevated protein content in peas (Stoddard and Marshall 1990).

\section{Greenhouse studies}

The field pea varieties/lines showed a significant difference in number of nodules plant ${ }^{-1}(p=0.0201)$ (Table 2). The highest number of nodules plant ${ }^{-1}$ was obtained with the line MT632 (14), which were at par with lines MT457 (11) and MT190 (13). No significant differences were observed among different pea lines/varieties for nodule fresh weight. The mean fresh weight of nodules was $0.105 \mathrm{~g}$. Similarly to the nodule fresh weight, no significant differences were observed for above and below ground biomass plant $^{-1}$, root, and shoot heights among different pea lines/varieties. An average above and below ground biomass weights were 1.38 , and $0.76 \mathrm{~g}$, respectively. An average root and shoot length of all lines/varieties were found to be 19.3 , and $21.6 \mathrm{~cm}$, respectively.

Similarly to the above and below ground biomass plant ${ }^{-1}$, no significant differences were observed in total dried biomass $\operatorname{pot}^{-1}(\mathrm{P}=0.1716)$, with mean biomass of $17.7 \mathrm{~g} \mathrm{pot}^{-1}$. Total plant $\mathrm{N}$ uptake pot $^{-1}$ did not differ significantly among different dry pea lines/varieties, the lines MT632 and MT190 show the highest $\mathrm{N}$ uptake $\left(0.730\right.$, and $0.768 \mathrm{~g} \mathrm{pot}^{-1}$, respectively) resulted from the more biomass accumulation with longer root and shoot heights. Vigor Indices I and II also did not show any significant difference (Table 2). However, the highest Vigor Index I was achieved with line MT632 accompanied with more shoot length $(26.0 \mathrm{~cm})$ as compared to other lines/varieties. The highest Vigor Index II was obtained with variety Majoret and line MT632, which were resulted from their high germination rates, and biomass respectively. This shows that other than plant heights and biomass, seedling emergence has huge impacts on vigor indices. Taweekul et al. (1998) found a marked difference in seedling emergence among seed lots of two field pea cultivars Beacon and Whero resulted in 54-60\% less total dry matter and a 57-68\% seed yield reduction. Earlier research (Egli and Burris 1971; Egli and TeKrony 1979; Hampton and Scott 1982) also reported reductions in seed yield from planting of low vigor seed resulted from lower plant populations. Moreover, the varieties with higher seed vigor indices resulted from more seedling emergence; biomass production can provide a better competition to weeds and can improve the grain yield. Dias et al. (2011) found that plants developed from high and intermediate seed vigor gave the best results against weeds competition by reducing weed dry mass accumulation and gave higher yields.

\section{Incubation studies}

In line with greenhouse experiment, the longest shoot length was observed with the line MT632 $(3.20 \mathrm{~cm})(p<0.0001)$, and variety Cruiser had the shortest shoot length of $0.92 \mathrm{~cm}$ (Table 3$)$. An average shoot length was $2.15 \mathrm{~cm}$ after 8 days of incubation. In contrast to greenhouse experiment, a significant difference was observed in below-ground (root) lengths $(p=0.0048)$ (Table 3). Line MT457 showed significantly longest root length $(11.28 \mathrm{~cm})$ as compared to other lines/varieties. Variety DS Admiral has shortest root length of $7.02 \mathrm{~cm}$. An average root length observed in incubator was $8.93 \mathrm{~cm}$. A significant difference was also observed among lines/varieties for total biomass $(p<0.0001)$. Highest 
Table 3. Evaluation of different pea varieties/lines for vigor indices in incubator.

\begin{tabular}{lcccccc}
\hline Line/Variety & $\begin{array}{c}\text { Shoot length } \\
(\mathrm{cm})\end{array}$ & $\begin{array}{c}\text { Root length } \\
(\mathrm{cm})\end{array}$ & $\begin{array}{c}\text { Biomass/seedling } \\
(\mathrm{g})\end{array}$ & Total biomass $(\mathrm{g})$ & Vigor index I & Vigor index II \\
\hline MT632 & 3.20 & 9.07 & 0.449 & 4.49 & 1202 & 44.03 \\
MT460 & 2.31 & 9.20 & 0.483 & 4.83 & 1128 & 47.34 \\
MT457 & 2.35 & 11.28 & 0.462 & 4.62 & 1335 & 45.29 \\
Delta & 1.19 & 9.33 & 0.449 & 4.49 & 1052 & 44.87 \\
DS Admiral & 2.45 & 7.02 & 0.494 & 4.81 & 946 & 49.37 \\
Majoret & 2.65 & 7.57 & 0.462 & 4.62 & 981 & 44.40 \\
Cruiser & 0.92 & 9.19 & 0.490 & 4.21 & 971 & 47.04 \\
MT190 & 2.11 & 8.82 & 0.471 & 4.71 & 1093 & 47.13 \\
Mean & 2.15 & 8.93 & 0.470 & 4.63 & 1089 & 46.2 \\
$p$-Value & $<0.0001$ & $\mathbf{0 . 0 0 4 8}$ & 0.1086 & $<0.0001$ & 0.0525 & 0.0628 \\
LSD & 0.82 & 1.71 & NS & 0.152 & NS & NS \\
\hline
\end{tabular}

Bold values represent significant values at $p<0.05$

biomass was observed with line MT460 (4.83 g) and highest yielding variety DS Admiral (4.81 g). In line with the greenhouse experiment, no significant differences were observed among different lines/varieties for Vigor Indices I and II.

\section{Correlations between seed vigor indices and other parameters}

A significant and positive correlation was observed among greenhouse and incubation studies for biomass weights per seedling or plant $(r=0.46, p=0.0030)$ and Vigor index I $(r=0.41, p=0.0089)$. However, no significant correlation for Vigor Index II was observed between greenhouse and incubation studies $(r=0.11, p=0.489)$. Further, in greenhouse studies, correlation analysis was done to find relationship between different variables such as biomass, vigor indices, with yield and seed protein content obtained from field experiment (Table 4). The data showed that a positive and significant correlation $(r=0.846, p<0.0001)$ was observed between total biomass and Vigor Index I. Total $\mathrm{N}$ uptake showed a positive and significant correlation with total biomass and Vigor Index I. As plant $\mathrm{N}$ uptake is the product of biomass with plant $\mathrm{N}$ concentration, indicating that the capacity of a plant for $\mathrm{N}$ accumulation was substantially influenced by dry matter. Takeda and Frey (1979) observed that the plants with greater dry matter have a greater grain yield per plant, as total plant dry matter is one of the factors determining grain yield. Results also showed that the correlation of both Vigor Indices to plant $\mathrm{N}$

Table 4. Pearson correlation coefficients and p-values (in parenthesis) showing the association between selected measured parameters and level of significance for the dry pea lines/varieties for studies done in greenhouse and field studies.

\begin{tabular}{|c|c|c|c|c|c|c|c|}
\hline \multirow[b]{2}{*}{ Variables } & \multicolumn{7}{|c|}{ Pearson correlation coefficient Prob $>|r|$ under $\mathrm{H} 0$ : $\mathrm{Rho}=0$} \\
\hline & Total biomass & Vigor I & Vigor II & Total N uptake & Protein content & Yield & Total protein \\
\hline Total biomass & - & - & - & - & - & - & - \\
\hline Vigor I & $\begin{array}{c}0.846 \\
(<0.0001)\end{array}$ & - & - & - & - & - & - \\
\hline Vigor II & $\begin{array}{l}0.245 \\
(0.0937)\end{array}$ & $\begin{array}{c}0.190 \\
(0.1956)\end{array}$ & - & - & - & - & - \\
\hline Total N uptake & $\begin{array}{c}0.374 \\
(\mathbf{0 . 0 3 4 8})\end{array}$ & $\begin{array}{c}0.481 \\
(\mathbf{0 . 0 0 5 3})\end{array}$ & $\begin{array}{l}-0.548 \\
(\mathbf{0 . 0 0 1 2})\end{array}$ & - & - & - & - \\
\hline Protein content & $\begin{array}{l}-0.123 \\
(0.5338)\end{array}$ & $\begin{array}{l}-0.117 \\
(0.5517)\end{array}$ & $\begin{array}{l}0.077 \\
(0.6973)\end{array}$ & $\begin{array}{c}0.058 \\
(0.7689)\end{array}$ & - & - & - \\
\hline Yield & $\begin{array}{c}0.081 \\
(0.6824)\end{array}$ & $\begin{array}{c}0.232 \\
(0.2340)\end{array}$ & $\begin{array}{c}0.268 \\
(0.1672)\end{array}$ & $\begin{array}{c}-0.267 \\
(0.1703)\end{array}$ & $\begin{array}{c}-0.062 \\
(0.7529)\end{array}$ & - & - \\
\hline Total protein & $\begin{array}{c}-0.030 \\
(0.8785)\end{array}$ & $\begin{array}{c}0.098 \\
(0.6198)\end{array}$ & $\begin{array}{c}0.260 \\
(0.1810)\end{array}$ & $\begin{array}{c}-0.157 \\
(0.4253)\end{array}$ & $\begin{array}{c}0.653 \\
(\mathbf{0 . 0 0 0 2})\end{array}$ & $\begin{array}{c}0.714 \\
(<0.0001)\end{array}$ & - \\
\hline
\end{tabular}

Total biomass, Vigor Indices, and total $\mathrm{N}$ uptake were obtained from greenhouse.

Protein content, yield, and total protein were obtained from field.

Bold values represent significant values at $p<0.05$. 
Table 5. Pearson correlation coefficients and $p$-values (in parenthesis) showing the association between selected measured parameters and level of significance for the dry pea lines/varieties for studies done in incubator and field studies.

\begin{tabular}{lcccccc}
\hline & \multicolumn{5}{c}{ Pearson correlation coefficient Prob $>|\mathrm{r}|$ under H0: Rho $=0$} \\
\cline { 2 - 6 } Variables & Total biomass & Vigor I & Vigor II & Protein content & Yield & Total protein \\
\hline Total biomass & - & - & - & - & - \\
Vigor I & 0.016 & - & - & - & - \\
& $(0.8973)$ & & & - & - \\
Vigor II & 0.073 & -0.166 & - & - & - \\
& $(0.5641)$ & $(0.1898)$ & & - & - \\
Protein content & -0.119 & -0.115 & -0.226 & & - \\
Yield & $(0.3808)$ & $(0.3991)$ & $(0.0944)$ & & - \\
& -0.077 & -0.103 & -0.082 & -0.062 & \\
Total protein & $(0.5723)$ & $(0.4505)$ & $(0.5459)$ & $(0.6484)$ & 0.653 & - \\
& -0.134 & -0.170 & -0.215 & 0.714 & $(<0.0001)$ \\
\hline
\end{tabular}

Total biomass, Vigor Indices, and total $\mathrm{N}$ uptake were obtained from greenhouse.

Protein content, yield, and total protein were obtained from field.

Bold values represent significant values at $p<0.05$.

uptake is significant and contrasting. Vigor Index I had a positive correlation while vigor Index II had a negative correlation with total $\mathrm{N}$ uptake by all plants in a pot.

A comparison of seed yield and protein content observed in field with agronomic parameters of dry pea lines/varieties observed in greenhouse and incubation studies did not reveal any significant correlations (Table 4 and 5). The correlation between grain yield and protein content was also observed to be non-significant $(r=-0.062, p=0.6484)$. Al-Karaki and Ereifej (1999) also observed a negative correlation between pea seed yield and seed protein concentrations and found that seeds of the variety Praire No. 11 had the highest protein concentration among other cultivars, and it produced the lowest seed yield. Ali-Khan and Youngs (1973) also found non-significant correlation between field pea seed protein content and yield and mentioned that selection for high protein should not be accompanied by deleterious effects on the other characters. Henry, Slinkard, and Hogg (1995) also demonstrated that the protein content of pea seeds decreases as seed yields increase. Total protein (product of yield and protein concentration) showed a positive significant correlation with yield $(p<0.0001)$ and protein content $(p=0.0002)$.

\section{Conclusions}

The dry pea lines/varieties differ significantly in nodule numbers and grain yield only. The variety DS Admiral, with the lowest protein content, showed the highest yield potential; however, the line MT190, with similar protein content, had the lowest yield potential. Also, variety Majoret has higher yield potential (at par with DS Admiral) along with highest protein content (23.4\%), showing that yield and seed protein content varied among genotypes and did not show any correlation between yield and protein content. Correlation analysis also showed non-significant relation between yield and seed protein content. Studies showed a positive and significant correlation between biomass and Vigor Index I in greenhouse only. The results of the current study indicated that Vigor Indices obtained in greenhouse and incubation studies did not reveal any significant relationship with seed yield and protein content obtained in the field, indicating that more efforts are needed to evaluate the different lines/varieties for higher yield potential and protein content at the earlier stages of growth.

\section{Acknowledgment}

The authors want to acknowledge the field and greenhouse technical support of EARC staff. 


\section{Funding}

The funding support for this study came from Montana State MREDI grant and Montana Agricultural Experiment Station fund.

\section{References}

Abdul-Baki, A., and J. D. Anderson. 1973. Vigor determination in Soybean seed by multiple criteria. Crop Science 13:630-33.

Acikgoz, E. et al. 2009. Genotype $\times$ environment interaction and stability analysis for dry matter and seed yield in field pea (Pisum sativum L.). Spanish Journal of Agricultural Research 27:96-106.

Ali-Khan, S. T., and C. G. Youngs. 1973. Variation in protein content of field peas. Canadian Journal of Plant Science 53:37-41.

Al-Karaki, G. N., and K. I. Ereifej. 1999. Relationships between seed yield and chemical composition of field peas grown under semi-arid Mediterranean conditions. Journal of Agronomy and Crop Science 182:279-84.

Atak, M., M. D. Kaya, G. Kaya, M. Kaya, and K. M. Khawar. 2008. Dark green colored seeds increase the seed vigor and germination ability in dry green pea (Pisum sativum L.). Pakistan Journal of Botany 40 (6):2345-54.

Atta, S., S. Maltese, and R. Cousin. 2004a. Protein content and dry weight of seeds from various pea genotypes. Agronomie 24:257-66.

Atta, S., S. Maltese, P. Marget, and R. Cousin. 2004b. $15 \mathrm{NO}_{3}$ assimilation by field pea Pisum sativum L. Agronomie 24:85-92.

Bedford, L. Y. 1974. Conductivity tests in commercial and hand-harvested seed of pea cultivars and their relation to field establishment. Seed Science and Technology 2:323-35.

Bhéring, M. C., R. F. Silva, E. M. Alvarenga, and D. C. F. S. Dias. 1999. Methodology of the tetrazolium test for bean seeds $=$ Metodologia do teste de tetrazólio em sementes de feijão. In Seed vigor: Concepts and testing =Vigor de sementes: conceitos e testes, eds F. C. Krzyzanowski, R. D. Vieira, and J. B. França-Neto, 8.3.1-8.3.10. Londrina, PR, Brazil: ABRATES.

Bittencourt, S. R. M., and R. D. Vieira. 1999. Methodology of the tetrazolium test for peanut seeds = Metodologia do teste de tetrazólio em sementes de amendoim. In Seed vigor: Concepts and testing = Vigor de sementes: Conceitos e testes, eds F. C. Krzyzanowski, R. D. Vieira, and J. B. França-Neto, 8.2.1.-8.2.8. Londrina, PR, Brazil: ABRATES.

Borowska, J., R. Zadernowski, and I. Konopka. 1996. Composition and some physical properties of different pea cultivars. Nahrung 40:74-78.

Caseiro, R. F., and J. Marcos-Filho. 2000. Alternative methods for evaluation of corn seed vigor by the cold test. Scientia Agricola 57:459-66.

Cataldo, D. A., L. E. Schrader, D. M. Peterson, and D. Smith. 1975b. Factors affecting seed protein concentration in oats. I. Metabolism and distribution of $\mathrm{N}$ and carbohydrate in two cultivars that differ in grain protein concentration. Crop Science 15:19-23.

Chalk, P., C. Smith, S. Hamilton, and P. Hopmans. 1993. Characterization of the $\mathrm{N}$ benefit of a grain legume (Lupinus angustifolius L.) to a cereal (Hordeum vulgare L.) by an insitu $15 \mathrm{~N}$ isotope dilution technique. Biology and Fertility of Soils 15:39-44.

Chen, C., K. Neill, M. Burgess, and A. Bekkerman. 2012. Agronomic benefit and economic potential of introducing fall-seeded pea and lentil into conventional wheat-based crop rotations. Agronomy Journal 104:215-24.

Chen, C., M. Westcott, K. Neill, D. Wichman, and M. Knox. 2004. Row configuration and nitrogen application for barley-pea intercropping in Montana. Agronomy Journal 96:1730-38.

Chiquito, A. A., F. G. Gomes-Junior, and J. Marcos-Filho. 2012. Assessment of physiological potential of cucumber seeds using the software Seedling Vigor Imaging System (SVIS). Revista Brasileira De Sementes 34:255-63.

Cox, M. C., C. O. Qualset, and D. W. Rains. 1985a. Genetic variation for nitrogen assimilation and translocation in wheat. I. Dry matter and nitrogen accumulation. Crop Science 25:430-35.

Delouche, J. C. 1980. Environmental effects on seed development and seed quality. Horticultural Science 15:775-80.

Dias, M. A. N., V. H. V. Mondo, and S. M. Cicero. 2010. Maize seed vigor and weed competition. Brazilian Seed Journal 32:93-101.

Dias, M. A. N., T. L. F. Pinto, V. H. V. Mondo, S. M. Cicero, and L. G. Pedrini. 2011. Direct effects of soybean seed vigor on weed competition. Brazilian Seed Journal 33 (2):346-51.

Egli, D. B., and J. S. Burris. 1971. Effects of soybean seed vigour on field performance. Agronomy Journal 63:536-38.

Egli, D. B., and D. M. TeKrony. 1979. Relationship between soybean seed vigour and yield. Agronomy Journal 71:75559.

Eppendorfer, W. H., and S. W. Bille. 1974. Amino acid composition as a function of total-N in pea seeds grown on two soils with $\mathrm{P}$ and $\mathrm{K}$ additions. Plant Soil 4:33-39.

Falconer, D. S., and T. F. C. Mackay. 1995. Introduction to Quantitative Genetics, 4th ed, pp. 122-143. Harlow, UK: Addison Wesley, Longman. 
Hampton, J. G., and D. J. Scott. 1982. Effect of seed vigour on garden pea production. New Zealand Journal of Agricultural Research 25:289-294.

Hatfield, J. L., and D. L. Karlen. 1994. Sustainable agriculture systems. Boca Raton, FL: Lewis Publ.

Helmer, J. D., J. C. Delouche, and M. Lienhard. 1962. Some indices of vigor and deterioration in seed of crimson clover. Proceedings of the Association of Official Seed Analysts 52:154-61.

Henry, H. L., A. E. Slinkard, and T. J. Hogg. 1995. The effect of phosphorus fertilizer on establishment, yield, and quality of pea, lentil, and faba bean. Canadian Journal of Plant Science 75:395-98.

Herridge, D., H. Marcellos, W. Felton, G. Turner, and M. Peoples. 1995. Chickpea increases soil-N fertility in cereal systems through nitrate sparing and $\mathrm{N}_{2}$ fixation. Soil Biology and Biochemistry 27:545-51.

International Seed Testing Association [ISTA]. 1995. Seed vigor. In Handbook of Vigor Test Methods. eds. J. G. Hampton and D. M. TeKrony, 3rd ed, p. 117. Zurich: ISTA.

International Seed Testing Association [ISTA]. 2014. Seed Vigor Testing. In International Rules for Seed Testing. Zurich, Bassersdorf, Switzerland.

Khajeh-Hosseini, M., A. A. Powell, and I. J. Bingham. 2003. The interaction between salinity stress and seed vigor during germination of soybean seeds. Seed Science and Technology 31:715-25.

Lhuillier-Sondélé, A., N. G. Munier-Jolain, and B. Ney. 1999b. Influence of nitrogen availability on seed nitrogen accumulation in pea. Crop Science 39:1741-48.

Marcos-Filho, J. 2015. Seed vigor testing: An overview of the past, present and future perspective. Scientia Agricola 72 (4):363-74.

Matthews, S., and W. T. Bradnock. 1967. The detection of seed samples of wrinkle-seeded peas (Pisum sativum L.) of potentially low planting value. Proceedings of the International Seed Testing Association 32:553-63.

Matthews, S., and M. Khajeh-Hosseini. 2007. Length of the lag period of germination and metabolic repair explain vigor differences in seed lots of maize. Seed Science and Technology 35:200-12.

Mckenzie, D. B., and D. Spooner. 1999. White lupin: An alternative to pea in oat-legume forage mixtures grown in New Foundland. Canadian Journal of Plant Science 79:43-47.

McLean, L. A., F. W. Sosulski, and C. G. Youngs. 1974. Effects of nitrogen and moisture on yield and protein in field peas. Canadian Journal of Plant Science 54:301-305.

Miller, P. R., A. Bekkerman, C. A. Jones, M. H. Burgess, J. A. Holmes, and R. E. Engel. 2015. Pea in Rotation with Wheat Reduced Uncertainty of Economic Returns in Southwest Montana. Agronomy Journal 107:541-550.

Miller, P. R., B. G. McConkey, G. W. Clayton, S. A. Brandt, J. A. Staricka, A. M. Johnston, G. P. Lafond, B. G. Schatz, D. D. Baltensperger, and K. E. Neill. 2002. Pulse crop adaptation in the Northern great plains. Agronomy Journal 94:261-72.

Mohammed, Y. A., C. Chen, K. McPhee, P. Miller, K. McVay, J. Eckhoff, P. Lamb, J. Miller, Q. Khan, B. Bohannon, M. Knox, and J. Holmes. 2016. Yield performance and stability of dry pea and lentil genotypes in semi-arid cereal dominated cropping systems. Field Crop Research 188:31-40.

Nikolopoulou, D., K. Grigorakis, M. Stasini, M. N. Alexis, and K. Iliadis. 2007. Differences in chemical composition of field pea (Pisum sativum) cultivars: Effects of cultivation area and year. Food Chemistry 103:847-852.

Pandey, S., and E. T. Gritton. 1975. Protein levels in developing and mature pea seeds. Canadian Journal of Plant Science 55:185-90.

Pate, J. S., and A. M. Flinn. 1977. Fruit and seed development. In: The physiology of garden pea, Eds. J. F. Sutcliffe, and J. S. Pate, 431-68. New York: Academic Press.

Perry, D. A. 1967. Seed vigor and establishment of peas. Proceedings of the International Seed Testing Association 32:3-12.

Perry, D. A. 1969. A vigor test for peas based on seedling evaluation. Proceedings of International Seed Testing Association 34:265-70.

Perry, D. A. 1970. The relation of seed vigor to field establishment of garden pea cultivars. Journal of Agricultural Science 74:343-48.

Perry, D. A. 1987. Report of the vigor test committee 1974-1977. Seed Sciences Technical 6:159-81.

Powell, A. A., R. Don, R. Haigh, G. Phillips, J. H. B. Tonkin, and O. E. Wheaton. 1984. Assessment of repeatability of the controlled deterioration vigor test both within and between laboratories. Seed Science and Technology 12:649-57.

Robertson, R. N., H. R. Highkin, J. Smydzuk, and F. W. Went. 1962. The effect of environmental conditions on the development of pea seeds. Australian Journal of Biological Science 15:1-15.

Salon, C., N. G. Munier-Jolain, G. Duc, A.-S. Voisin, D. Grandgirard, A. Larmure, R. J. N. Emery, and B. Ney. 2001. Grain legume seed filling in relation to nitrogen acquisition: A review and prospects with particular reference to pea. Agronomie 21:539-52.

SAS. 2001. SAS/STAT Guide. Cary, NC: SAS Inst. Inc.

Scott, D. J., and R. C. Close. 1976a. An assessment of seed factors affecting field emergence of garden pea seed lots. Seed Science and Technology 4:287-300.

Singhal, N. C., K. N. Srivastava, and S. L. Mehta. 1989. Pattern of dry matter and protein accumulation in developing wheat seeds and their relationship. Indian Journal of Genetics 49:95-102.

Stoddard, F. L., and D. R. Marshall. 1990. Variability in grain protein in Australian hexaploid wheats. Australian Journal of Agricultural Research 41:277-88. 
Sweeney, R. A. 1989. Generic combustion method for determination of crude protein in feeds: Collaborative study. Journal - Association of Official Analytical Chemists 72 (5):770-74.

Takeda, K., and K. J. Frey. 1979. Protein yield and its relationship to other traits in backcross populations from an Avena sativa $\times$ A. sterilis cross. Crop Science 19:623-28.

Tar'an, B., T. Warkentin, D. J. Somers, D. Miranda, A. Vandenberg, S. Blade, and D. Bing. 2004. Identification of quantitative trait loci for grain yield, seed protein concentration, and maturity in field pea (Pisum sativum L.). Euphytica 136:297-306.

Taweekul, N., G. D. Hill, B. A. McKenzie, and M. J. Hill. 1998. Filed performance of field pea seeds with varying vigour levels. In Proceedings of agronomy society of New Zealand, 99-105. Available online: tps://www.agronomysociety. org.nz/files/1998_17._Field_performance_field_pea_seeds.pdf

USDA-NASS. 2016. Data and statistics/quick facts. Washington, DC, USA: USDA-NASS.

Wang, N., and J. K. Daun. 2004. Effect of variety and crude protein content on nutrients and certain antinutrients in field peas (Pisum sativum). Journal of the Science of Food and Agriculture 84:1021-29.

Wang, N., D. W. Hatcher, T. D. Warkentin, and R. Toews. 2010. Effect of cultivar and environment on physicochemical and cooking characteristics of field pea (Pisum sativum). Food Chemistry 118:109-115.

Yoneyama, T., and J. Ishizuka. 1982. 15N study on the partitioning of the nitrogen taken by soybeans from atmospheric dinitrogen, medium nitrate or ammonium. Soil Science and Plant Nutrition 28:451-61. 